\title{
Passports, Citizenship, Residency and Asylum: The Meanings of Decolonisation in Lesotho
}

\author{
John Aerni-Flessner
}

To cite this article: John Aerni-Flessner (2018): Passports, Citizenship, Residency and Asylum: The Meanings of Decolonisation in Lesotho, The Journal of Imperial and Commonwealth History, DOI: $10.1080 / 03086534.2018 .1457215$

To link to this article: https://doi.org/10.1080/03086534.2018.1457215

\section{曲 Published online: 05 Apr 2018.}

Submit your article to this journal

Q View related articles $₫$

View Crossmark data $\nearrow$ 


\title{
Passports, Citizenship, Residency and Asylum: The Meanings of Decolonisation in Lesotho
}

\author{
John Aerni-Flessner \\ Michigan State University, East Lansing, MI, USA
}

\begin{abstract}
In late colonial Basutoland and early independence Lesotho, the issue of who could access citizenship rights and passports became increasingly important. Political refugees fleeing apartheid South Africa took up passports on offer in the territory to further their political work. Basotho residents also took up passports in increasing numbers as a way of safeguarding their economic, social and political rights on both sides of the border. The lure of a Citizens of the United Kingdom and Colonies (CUKC) passport drew refugees to Basutoland in the early 1960s, but it was South Africa's decision to leave the Commonwealth in 1961 that spurred many in Lesotho to formalise their imperial citizenship as well, even as independence for Lesotho became increasingly likely. The stories of those taking up papers illuminate how citizenship became a space for contestation between individuals and governments. The stories also show how the concept of the transfer of power does not accurately reflect the ways in which the sovereignty of newly independent African states, apartheid South Africa and the United Kingdom were all limited by a series of decisions made in the late colonial period. Tracing these stories helps us better understand the limitations of the term 'decolonisation' for reflecting the understandings and complications of citizenship in 1960s and 1970s southern Africa.
\end{abstract}

\section{KEYWORDS}

Lesotho; politics; apartheid; refugees; borders; asylum; citizenship; South Africa

In June 2007, as political fall-out from a split in the ruling Lesotho Congress of Democracy, journalist the Rev. Adam Lekhoaba revealed that Prime Minister Pakalitha Mosisili possessed valid South African identity documents, despite the fact that Lesotho constitutionally prohibited dual citizenship. ${ }^{1}$ Mosisili's papers came from his time working at South African universities in the 1980s and early 1990s. The Lesotho government acknowledged the existence of these documents, but denied that they had conferred citizenship on Mosisili, saying they were necessary to formalise his residency status at the time for employment purposes. The political storm about the identity documents 
rapidly blew over because many Basotho were in similar situations where they either possessed or desired to possess formal South African papers that would allow them to more easily visit family, find work or get better medical care across the border. The contestation over both residency rights and citizenship in Lesotho and South Africa that the issue raised was not new. The story presented here shows both the continuities and the ruptures in border and passport policy at the transfer of power, as citizenship disputes in late colonial and newly independent Lesotho reflected the limits of state sovereignty for both the new state and the former colonial power, Great Britain.

These contestations in Lesotho were especially salient from the late 1950s to the 1970s - a period of great political change that included South Africa's 1961 commonwealth exit, Lesotho's 1966 independence and multiple periods of regional upheaval as various apartheid crackdowns created large numbers of political refugees. ${ }^{2}$ Joe Matthews, a leader in both the African National Congress (ANC) and the South African Communist Party (SACP), fled to Lesotho in 1960 to avoid arrest in the wake of the Sharpeville massacre. Despite the misgivings of the colonial government because of his known political affiliations, Matthews gained an indefinite residence permit that allowed him to live legally in Lesotho. For Matthews proximity to South Africa combined with the ability to acquire residency rights, British citizenship and a Citizen of the UK and Colonies (CUKC) passport after one year's residence were the primary draws of the territory. Utilising the freedom of movement that this document conferred, Matthews made multiple trips behind the Iron Curtain to raise funds for South African liberation organisations as well as local political parties. His case is representative of how politically connected South Africans made use of late colonial residency and citizenship laws to further anti-apartheid work.

Matthews was unusual among refugees in that he successfully obtained both a residency permit and a British passport. Many refugees struggled to obtain permanent legal residency because that status typically required a successful claim to 'belonging' in Lesotho. The resistance to granting refugees this status came from colonial officials, but also from Basotho chiefs and politicians. In examining some of these refugee and asylum stories, this article heeds Rosenthal's call to utilise the experiences of refugees during decolonisation to better understand how people were conceiving of national communities and nation-building processes as they attempted to construct boundaries. ${ }^{3}$ This article also makes use of the stories of prominent political refugees because of archival limitations that make re-creating the experience of ordinary Basotho attempting to navigate similar boundaries difficult. The national archives in Maseru do not contain accessible records from the late colonial period and there is only one partial district record preserved at the archives of the National University of Lesotho. But recover these voices and stories we must to fully understand how people understood citizenship and sovereignty. This article therefore uses the available fragments also to elucidate how Basotho without extensive political 
contacts attempted to negotiate and utilise passports and border policy for their own ends.

\section{Passports and Citizenship}

The border between South Africa and Lesotho, the 'only country in the world entirely surrounded by another independent state', is an important place at which to study questions of citizenship, sovereignty and passports. ${ }^{4}$ The border is unusually salient in Lesotho because of its porous nature and its ubiquity for citizens in an enclave country. Shallow rivers, unfenced mountains and broad expanses of farmland allowed for easy crossing of the frontier for those who could not or did not want to utilise the formal processes. An ethnic Basotho majority in most communities in the eastern Orange Free State and Lesotho, combined with a shared imperial and commonwealth history made legally crossing the border more an administrative formality than an obstacle through much of the nineteenth and early twentieth centuries. ${ }^{5}$ Most Basotho had family on both sides of the border and the majority of Basotho who had formal employment did so in South Africa, whether seasonally or as longerterm migrants. The long history of Britain treating Lesotho as a labour reserve with inadequate infrastructure and social services also meant that Basotho regularly crossed to access services from shopping to medical care.

In the 1960s, however, there was a new and different emphasis on documents and controls that raised the stakes on who could legally cross and who could claim 'belonger' status in Lesotho. South Africa, Lesotho and the United Kingdom all failed to fully monopolise the 'legitimate means of movement' and hence claim sovereignty because people were able to manoeuvre around passport restrictions. ${ }^{6}$ While South Africa was actively working to limit the ability of black South Africans to access passports in the 1960s, it was the changing constitutional statuses of South Africa and Lesotho that precipitated a rush by politically active citizens and ordinary Basotho to obtain passports, especially in the wake of South Africa's 1961 exit from the Commonwealth and Lesotho's 1966 independence. $^{7}$

Passports are effective for examining the limits of state sovereignty because the number of people, both citizens and refugees, attempting to access passports spiked dramatically during this time. With many people obtaining passports despite the objections of particular states, studying passports shows that in the decolonisation era states were often unable to 'effectively distinguish between citizens/subjects and possibly interlopers, and regulat[e] the movements of each'. 8 One reason the number of passport applicants spiked in the 1960s was the apartheid state's crackdown on political activity. The lure of citizenship in Lesotho-a British citizenship in the colonial period and a national citizenship after independence-drew individuals to the territory, and highlighted for locals the benefits of possessing formal documents to 
prove and validate belonging. Thus, by the end of the 1960s, a majority of Basotho possessed a passport.

Examining questions of local belonging and citizenship in the late empire takes the study of British citizenship in the 1960s in a new direction. Many scholars have focused on how the right of access to Britain for colonial subjects altered domestic debates about citizenship, belonging and what it meant to be British. ${ }^{9}$ In Lesotho the 1962 Commonwealth Immigrants Act had little to no impact, despite it being a key turning point in debates about colonial access to the UK back in London. Rather, South Africa's decisions to crack down on political opposition in 1960 and to leave the Commonwealth in 1961, implementing border controls with the three High Commission Territories for the first time, were the catalysts for a sharp increase in citizenship and passport applications.

The trend of increased passport acquisition did not abate after Lesotho's 1966 independence, but the late colonial policies constrained in important ways the sovereignty of both the Lesotho and UK governments. Those who had gained British citizenship and residency in Lesotho were supposed to transform seamlessly into becoming Lesotho citizens, but concerns about the political activities of some of these individuals - couched in the language of national belongingmeant that some refugees found their citizenship status in legal limbo. State concerns about these people came from the fact that, as Salter notes, control over the movement of 'foreign nationals... reifies the international presence of the nation-state, constructs the border in its crossing ... and consequently creates the sovereign character of the state'. ${ }^{10}$ So, in the late 1960 s and early 1970 s, the possession of a passport continued to serve as a marker that a person could demand rights from the government. Conversely, the lack of official papers greatly handicapped individuals who could not claim 'belonger' status in new states. With access to passports controlled by a confusing and interlocking series of laws from multiple jurisdictions, attempting to untangle this Gordian knot challenged the idea that decolonisation could be a simple process for the colonisers or the colonised. The formal transfer of power in 1966, while important, was but one of many constitutional changes around independence that affected the ability of individuals and governments to define and claim sovereignty, citizenship and belonging.

\section{Moving beyond the National in Late Imperial and Post-colonial History}

The meanings of the border between Lesotho and South Africa are still live issues for many in Lesotho. Coplan notes that the porous nature of the border and the economic inequalities found on opposite sides led to 'a wide variety of strategic forms of dual residency and nationality' that are dealt with pragmatically by both governments, which generally 'turn a blind eye to dual nationality if the second identity is acquired legally. ${ }^{11}$ He has also traced how individuals understand and 
interact with the state controls inherent in the border, working to re-appropriate spaces that are part of greater national imaginings, even if they happen to lie on the other side of the physical border. ${ }^{12}$ Coplan's work tends to frame discussion within the narrow boundaries of national sovereignty, while this article builds from Goulbourne's note that British citizenship in the first half of the twentieth century 'was conferred on the individual "directly without reference to local citizenship"'. ${ }^{13}$ It is this facet of citizenship that makes it so intriguing to study. In the independence era, the lack of congruence between residency and citizenship rights greatly complicated efforts by governments to exercise sovereignty.

By narrating attempts at citizenship acquisition, this article heeds Bailkin's call to recast the 'archive of decolonization' to better understand the 'dismantling and reconfiguration of imperial power' by exposing the ability of individuals to utilise the policies of the empire for personal or political gain. ${ }^{14}$ Passports and citizenship also help us rethink decolonisation as a process that mattered to people beyond the small class of those holding governmental power. ${ }^{15}$ It also takes up Allman's challenge to write post-colonial history by narrating the complexity of the post-independence world through stories that rest not only on national archives. This text takes up her call to write stories that are 'both deeply and specifically national and yet profoundly global' by drawing on a multiplicity of sources from Lesotho, South Africa, the UK and the USA. ${ }^{16}$ The individuals who appear here were rooted in Lesotho and South Africa, but they also deployed international attention via NGOs, utilised international law and made multi-national appeals in their attempts to formalise rights and statuses. The article also helps us to rethink the meanings of the Commonwealth after the independence of colonies like Lesotho. ${ }^{17}$ Finally, this work extends to the colonies' analyses done by Matera and Perry on how peoples of African descent in London played key roles in changing the meaning of British citizenship and were part of meaningful transnational dialogues on race, human rights and democracy. ${ }^{18}$ The ubiquity of the cases and the ease with which so many individuals accessed transnational political networks suggest that similar issues around citizenship and passports were probably present in many other colonies and the post-independence Commonwealth. Plenty of individuals in Lesotho and South Africa understood that 'power in the empire was fragmented' and they could utilise this knowledge to further their own political and economic ends. $^{19}$

\section{Citizenship and Entry Laws}

In order to understand the legal world that passport applicants were entering, it is necessary to trace changes in citizenship law for the UK, South Africa and Basutoland/Lesotho through the early and middle decades of the twentieth century. The 1948 British Nationality Act expanded imperial citizenship in response to dominion efforts that superseded imperial structures and threatened 
to undermine the idea of the Commonwealth. ${ }^{20}$ The law made every resident of the colonies automatically a subject, and allowed these new subjects to gain citizenship, and thus passports, through registration. It also reaffirmed the right of free movement and entry into the United Kingdom for those who had the status of British subject. This aspect of the law became increasingly contentious as the membership of the 'new' Commonwealth increased and migration, especially from the Caribbean and the Indian subcontinent, increased in the 1950s and 1960s. ${ }^{21}$ As Basutoland was a crown colony, the 1948 law gave residents the right to take up citizenship, clearing the way for claims to passports by arrivals in the 1960s.

South Africa also changed its citizenship laws in 1948-49 when the National Party came to power on a platform of apartheid, Afrikaner nationalism and scepticism towards Britain and the Commonwealth. The Union of South Africa had first created a distinct category of South African nationality, that of 'Union National', in 1927 with the passage of the Nationality and Flags Act. This set up a situation of 'double nationality' whereby South Africans were both 'Union nationals' and 'British subjects'. ${ }^{22}$ The South African Citizenship Act of 1949 abolished the status of Union national and replaced it with a South African citizenship. The act also removed references to a common status for citizens of the Commonwealth, a provision aimed at discouraging residents of the 'new' commonwealth countries like India, Pakistan and Ceylon from attempting to take up South African citizenship. Additionally, the rule undergirded South African efforts to disenfranchise Africans within their borders in the coming years, efforts that would culminate in the 1970 law stripping the South African citizenship of Africans deemed to be citizens of the newly created 'Bantu Homelands' ${ }^{23}$ However, since South Africa was still a member of the Commonwealth, South Africans could still register as British subjects and receive a CUKC passport. ${ }^{24}$ For residents of Lesotho the 1949 law did not change their ability to freely enter South Africa because of the continued commonwealth ties. There remained no border controls between South Africa and the High Commission Territories (including Lesotho) until 1963, and people who obtained a signed pass from their local officials continued to move freely across the frontier. Local permissions gradually tightened through the 1950s with the imposition in South Africa of a formal pass system and crackdowns on Africans in urban areas. Still, as late as the mid-1950s, colonial officials and chiefs in Lesotho could still write a simple pass allowing Basotho to take up work and/or residence across wide swaths of rural South Africa. ${ }^{25}$

South Africa's departure from the Commonwealth on 31 May 1961 ended the open border policy. Overnight, Basotho in South Africa lost their 'belonger' status, and were considered aliens under the 1949 law. The South African government delayed the imposition of formal border controls several times between 1961 and 1 July 1963, largely because of how frequently Basotho crossed the border and how few Basotho had passports. The long history of easy movement 
between the two countries, particularly around labour migration, compelled many Basotho to apply for and receive passports after controls were announced. For politically active South Africans, the end of commonwealth ties made the three High Commission Territories more alluring because individuals could still obtain British citizenship there after a year's residency. ${ }^{26}$ South Africa's decision to leave the Commonwealth combined with the ongoing crackdown on the ANC and Pan-Africanist Congress (PAC) turned what had been a trickle of political refugees in the 1950s into a flood that would continue unabated through the 1980s.

The High Commission Territories were, however, not particularly well equipped to handle this influx of refugees because of their poverty and skeletal colonial administrations. The primary aim of Basotho leaders prior to the 1960s was protecting Lesotho's territorial independence from South Africa. When the 1909 Act of Union brought modern South Africa into being, it promised the eventual incorporation of Lesotho and the other High Commission Territories. The British would have preferred to hand the territories over to South Africa in 1909, but lobbying from Basotho chiefs, who sent a delegation to London, kept the territories from being subsumed under South Africa's direct political control. Still, the threat of incorporation hung over all political negotiations for the rest of the colonial period. Basotho chiefs and 1950s-60s political leaders feared that Britain would try to sell land in the territory to European settlers-something that had happened in virtually every other crown colony across the empire. The tenacious, single-minded focus from Basotho leaders kept Lesotho out of South African hands, despite repeated overtures. However, this focus also meant that when a new entrance and residency law came up for discussion in 1958, the national council failed to comprehend how the law would complicate efforts to define residency and citizenship.

Questions of Basotho accessing British citizenship came up from time to time in debates in 1950s Lesotho, but they were certainly not a major focus. In 1951, with members of the national council pressing the resident commissioner to define Lesotho's constitutional status and state definitively that incorporation was not part of British plans, he instead noted that there is 'no difference between a Crown Colony and a Protectorate except that people of a Crown Colony are British subjects whereas the others are only protected subjects'. ${ }^{27}$ Tangential to their more pressing worries about incorporation, the status of Basotho as British subjects eligible for citizenship elicited no comment from the representatives.

The main focus of discussions among Basotho chiefs and colonial administrators around the 1958 Entry and Residence Proclamation (ERP) was on how the law might impact the threat of incorporation. The act's ostensible purpose was to codify who qualified for residency rights and how migrants could legally enter the territory. There was almost no discussion about what might happen if a significant voluntary migration of individuals to Lesotho should occur. This was 
hardly surprising as Lesotho in the late 1950s was not attractive to migrants, being terribly poor with little existent infrastructure. It had attracted only a handful of political refugees prior to 1960. This population consisted generally of those fleeing immediate prosecution in South Africa or people who had familial contacts already in the territory. The ERP was a response to South Africa's 1956 Riotous Assemblies Act, which gave Union authorities the right to deport people from urban and 'proclaimed' areas. The worry in Lesotho was that South Africa would 'dump' unwanted, ethnically Basotho South Africans in the territory, since there was no statute on the books defining who had a legal claim to residency. Basotho chiefs feared that South African authorities would 'pour thousands of people in here that we don't want'. ${ }^{28}$ The discussion in the national council thus centred on how to define those who had a right to residency in the territory-what a birthright to the territory should entail and who was Basotho 'enough' to join the national community.

The fundamental disagreement was over what constituted a birthright. There was general agreement between Basotho representatives and colonial officials on the need to limit the number of people who could claim residency. Councillor Maqoaelane Hlekane argued that South African Basotho were part of a wider ethnic group, but were not members of the national community and thus had no claim to residency rights. They should 'remain our relatives; we shall keep on visiting them, and they will visit us, but [the council] should decide what sort of people we accept to fill up this country' ${ }^{29}$ Fellow councillor 'Mako Molapo took an even harsher view, calling Basotho not from Lesotho 'tsotsis [gangsters]', arguing that they should 'remain our cousins, but remain[e] in the country where they were born and where they got spoiled'. ${ }^{30}$ This hard stance against Sesotho-speaking, ethnic Basotho who happened to live in South Africa denied the long history of border crossing. Comprehensive figures are not available, and would not be particularly trustworthy because of the informal/illegal nature of so many crossings, but border crossing in both directions was a consistent theme in Lesotho's history. The late colonial period certainly saw no slowdown in the flow of migrants. New economic opportunities available in South Africa combined with the continued impoverishment and lack of arable land in Lesotho perhaps, made migration even more attractive.

Due to chiefly suspicions of the motives of British colonial officials, the 1958 ERP ended up cumbersome and hard to implement. Colonial officials were reluctant to push too hard for control over residency decisions because they feared losing the support of chiefs at a time when political developments in the territory were increasingly turbulent. ${ }^{31}$ One result of this was that most of the control over residency decisions remained in Basotho hands. This was in keeping with the administrative structure in colonial Basutoland that gave chiefs wide latitude to decide whether or not to accept arrivals. The new law automatically granted residency to those who could claim a birthright, defined 
as being born in the territory or to Basotho parents outside the territory who were properly registered. It created a series of control boards to decide the cases of those applying for residency who did not have a birthright. The first set of control boards at the district level could issue temporary residence permits ranging in duration from months to years, as well as permanent residence permits to those whose applications were accepted by a local chief. These boards had four members: the district or ward chief, the district commissioner and two Basotho members nominated by the district council.

The law left Basotho largely responsible for controlling access to residency in the late 1950s and early 1960s, and hence meant that local colonial subjects had control over a process through which people could obtain British citizenship, and passports, in the late empire. Like the district board, the central control board in Maseru-comprised of a chief, a colonial official and two nominated Basotho-could grant indefinite residence to those who wanted residency but who were not applying for membership in the national community. Common applicants to this board included missionaries, non-African traders and Africans not applying through chiefs, including refugees. ${ }^{32}$ Slight amendments to the act in 1960 reiterated that citizenship and residency rights were not coterminouseven an indefinite residence permit issued by the central control board did not give a person citizenship or 'belonger' status in Lesotho. The only reserved power in the law was for the British high commissioner who retained the right to declare persons prohibited immigrants, causing them to lose any residency rights. Overall, however, the ERP was the latest in a series of laws dating back to the nineteenth century that left Basutoland governed not by indirect rule, as with most of British colonial Africa, but by parallel rule. ${ }^{33}$ With three Basotho on the four-person boards that determined residency, and hence citizenship rights, colonial subjects were effectively acting as gatekeepers to imperial citizenship in the late empire.

In practice, however, the ERP was less a neat system of well-run boards with a logical progression and more often a confusing process, opaque and fairly easy to avoid if individuals were so inclined. The law required arrivals only to start the process within a month of setting foot in the territory if they planned to stay for more than three months, which left wide latitude for individuals to live in the territory without formal papers. Further, even if a decision on residency went against an applicant, the government had a hard time repatriating people, as public opinion in the UK and in Lesotho largely militated against handing people over to the apartheid regime. Within Lesotho, the chieftaincy, tasked with enforcement and implementation, did not eagerly embrace the new law. Accepting new 'belongers' had long been a strategy for Basotho chiefs to gain more influence relative to their peers in Lesotho by having more people eligible for taxation under their administration. ${ }^{34}$ Complaints in 1959 from resident commissioner Chaplin and paramount chief 'Mantsebo that other chiefs were not making migrants go through control boards suggest that many chiefs 
preferred to retain an individual prerogative over immigration and residency matters, rather than use the new law. ${ }^{35}$

The lack of enforcement by the chiefs of the provisions of the ERP was also reflective of continued tension between the chieftaincy and the colonial government over control of urban spaces in Lesotho. The nine small urban administrative centres were the only places in Lesotho under the direct control of the colonial government, and chiefs viewed them as lawless spaces. This was especially true for Maseru, which was seen as a haven for refugees. These criticisms were on point as Resident Commissioner Chaplin noted in 1959 that he was reluctant to order police sweeps in Maseru because they would net a number of politically sensitive refugees. These individuals would be in contravention of the ERP, but the colonial regime would be unable to deport them because of the strong connections these individuals had with anti-colonial and anti-apartheid organisations in the $\mathrm{UK}^{36}$ In the wake of Sharpeville, the number of politically sensitive individuals in Lesotho only increased. The independent government of Lesotho inherited this problem from the colonial administration in 1966, and the fate of political refugees remained a tricky political issue in Lesotho until the end of apartheid.

For all the problems the colonial government faced with enforcing the ERP on the (few) high-profile refugees in the territory in the late 1950s and early 1960s, it was much more easily enforced on individuals entering the territory who lacked international visibility and political connections. The only existent, though partial, district archives for Lesotho come from the northern district of Leribe, which was the jumping-off point for migrant labour from the central mountains and the northern part of the territory through the Ficksburg Bridge border post. A fragmentary record of Leribe local court cases from January to June of 1962 shows more than 20 cases brought under the ERP against individuals who did not have legal residency. All of the defendants were found guilty, and every one of those convicted chose to do time in jail rather than pay a fine of a few pounds. $^{37}$

The decision to serve time rather than pay the fine, along with the slowness with which some of the refugee cases proceeded (detailed later in this article), suggests the ERP ensnared mainly poor migrants. These people probably saw themselves as 'belongers' in Lesotho who could not prove their status with documentation. In order to be considered a 'belonger' a person needed to have been born in Lesotho or their parents must have registered their South African birth with the high commissioner's office. With many Basotho living illegally in South Africa, there was hesitancy from many Basotho to come before any authorities and register births, which meant that many who considered Lesotho their home and wished to return lacked the proper documentation. For those with no familial ties, Lesotho held little or no draw because of the almost complete dearth of formal employment prospects, and even a lack of an informal economy in much of the territory. The surnames of those convicted were, further, mostly names 
common in Lesotho like Moshoeshoe, Lebakeng, Matjola, Morake and Mokoena. These all point to the conclusion that most of those convicted of being in Lesotho 'illegally' probably felt that they 'belonged' to Lesotho. Without the international connections that high-profile political refugees had, and without papers to prove their status, these poor Basotho failed to gain access to the territory and the ERP served to evict them. The prevalence of these cases also suggests that long before independence many people understood the importance of passports and official papers to defend and protect residency rights.

\section{0 and after: Sharpeville, Refugees and Passports}

The massacre of pass protestors at Sharpeville in March 1960 and the subsequent banning of the ANC and PAC greatly increased the number of people seeking to leave South Africa. The three High Commission Territories-Basutoland, Bechuanaland Protectorate and Swaziland-were the only places bordering South Africa where refugees could seek asylum. Portugal still ruled Mozambique, South Africa ruled Namibia and European settlers maintained power in Southern Rhodesia. Lesotho might seem the least promising destination as it lacked international transportation connections or a border with any other state. Despite these limitations, Lesotho had the most developed political system of any of the High Commission Territories, was close to major South African population centres, offered arrivals the chance to access a CUKC passport after a year of residence and had more flexible rules for arrivals than the other territories. Under the ERP, a person who intended to stay for longer than three months had to report within a month to a control officer-police officer, chief or colonial official-to start the process of applying for a residency permit, but this meant no one had to report to the authorities immediately. Evading the ERP worked well for those looking to stay only a short time until they could move on or return to South Africa. However, the cases of Joe Matthews and Dr Arthur Elias showed how refugees could also make use of the law and the British citizenship they could obtain through it to further their own political work.

Vincent Joseph Gaobakwe Matthews was the son of ANC leader and academic Z. K. Matthews. He grew up in Alice, South Africa, the site of Fort Hare University College, where his father taught. Politicised from a young age -Oliver Tambo was one of his schoolteachers-he joined the ANC Youth League in 1944 and rapidly moved up, taking a seat on the ANC National Executive by the mid-1950s. He was also recruited into the already banned South African Communist Party (SACP) in 1958 and served on its Central Committee-the only individual in the late 1950s to sit on the central boards of both. At the time of Sharpeville, he was practising as an attorney in Durban. Matthews was arrested at 2 am on 30 March 1960 as the state of emergency went into effect, but released on a technicality later that morning, as the judge had not 
yet received a copy of the legal declaration from Cape Town by the time of his 9 am court appearance. ${ }^{38}$ Upon release, he drove straight to Lesotho. Matthews' connections in the territory included a close relationship with Basutoland Congress Party (BCP) leader Ntsu Mokhehle, as they had been classmates and members of the ANC Youth League together at Fort Hare. For Matthews, the biggest draw of Lesotho was the prospect of using Maseru as a base from which to continue the liberation struggle.

Matthews, unlike many poor or less well-connected migrants, could live openly in Maseru, much to the chagrin of the British colonial authorities. With so many arrivals living underground or at least attempting to surreptitiously avoid colonial officials, the colonial regime did not have a good handle on the number of people from South Africa present in the territory. British authorities in May 1960 thought there were around 50 refugees total in the High Commission Territory, but this number represented 'no more than our best guess'. ${ }^{39}$ At times the colonial authorities did not even know about the presence of some of the most important liberation struggle leaders. A June 1960 flight to Swaziland that Matthews arranged to get ANC leaders out of the territory, for instance, revealed the presence of three of the leaders to British intelligence for the first time. ${ }^{40}$ Zakes Mda, who had taken refuge in Lesotho with his father, PAC activist A. P. Mda, also noted that the 'Christian Council of Lesotho had a much [more] up-to-date list of refugees than the government'. ${ }^{41}$

Rather than attempting to claim political asylum, Matthews applied for an indefinite residence permit through the ERP, which was available to a wider range of outsiders. An indefinite permit required the applicant to have employment in the territory, and it conferred the advantage of allowing the applicant to live in urban Maseru rather than having to find a sympathetic chief. Matthews thus claimed residency on the basis of his professional skills as an attorney-a skill that was in short supply in late colonial Basutoland. He knew that a claim to national 'belonger' status would have been denied, and applying as a political refugee meant that the government would have had more latitude to terminate his status once the state of emergency in South Africa ended. The central control board approved his application in September 1961 'so long as practicing as an attorney in Basutoland'. ${ }^{42}$ The permit came through despite strong objections from the colonial government, which was well aware of Matthews' communist associations. The only colonial representative on the control board, Government Secretary Gordon Hector, argued strenuously against Matthews' application, 'draw[ing] the Board's attention to popular misgivings about Matthews' political activities and their potential impact on relations between the territory and South Africa'. ${ }^{43}$ Matthews' strong personal connections with politicians and Lesotho's constitutional monarch, Moshoeshoe II, allowed him to gain residency despite his known communist activities and the opposition of the colonial government. This legal residency allowed him to apply for and receive a CUKC passport in 1962. 
The availability of a UK passport was a key feature attracting him to the territory, and he had long planned to go to Lesotho if forced to flee South Africa. A UK passport, as he said in an interview, would give him the freedom to 'become the traveller [for the ANC and SACP] who could go out, come back, go where the leadership was in exile ... as a British citizen, with a passport and everything' ${ }^{44}$ While he utilised the passport on some trips outside the territory, for others he clandestinely slipped across the border to travel through Botswana. Matthews made at least four trips to Moscow and other communist countries between 1960 and 17 February 1965, when the high commissioner finally declared him a prohibited immigrant in all three High Commission Territories, nullifying his residence permit. ${ }^{45}$ The Matthews' pre-determined plan to head for Lesotho highlights how politically active South Africans knew about and understood both the Lesotho residency requirements and British citizenship law, and how they utilised both to further their political work.

ANC leader Dr Arthur Elias Letele was, unlike Matthews, a 'belonger' to Lesotho so he did not need to apply for residency through the ERP, but he too made use of the British citizenship on offer in the territory. Born in Maseru in 1916, his parents moved shortly thereafter to Ladybrand in the Orange Free State for work. Letele spent the rest of his childhood and early professional life in South Africa. Qualifying as a medical doctor in 1946, he set up a successful practice in Kimberley. Like Matthews he also joined the ANC Youth League in 1944, and was elected treasurer of the Kimberley branch in 1948. He was at the forefront of protests in Kimberley, being arrested multiple times in the 1950s. Letele gained national prominence by helping draft the Freedom Charter in 1955 and was elected national treasurer-general of the ANC in 1955. This led him to be one of the defendants, alongside Matthews and others, in the treason trial that started in 1956.

Arrested at his Kimberley home on 30 March 1960, Letele spent almost four months in jail after the declaration of the state of emergency. His birth in Lesotho, however, meant that he was a British subject, and so his arrest and detention attracted notice from British officials in South Africa. They had little desire to take up Letele's case because of his political work, and they did so largely because of public pressure from the anti-colonial lobby in the UK. ${ }^{46}$ Letele's ability to access a lawyer and to receive visits from his wife came about primarily because of his status as a British subject. With no charges filed against him over three months after his arrest, UK Labour MP Hilary Marquand raised questions in parliament about the continued detention of a British citizen on 30 June. This diplomatic pressure contributed to his release on 19 July, but in exchange for leaving jail he had to agree to move back to Lesotho within 30 days. $^{47}$

While Letele was displeased with deportation because it disrupted his successful medical practice and his political work, he too had planned for this contingency. He started paying South African income tax in 1948 with the opening of 
his medical practice in Kimberley, but he had also been paying general tax to the Basutoland government since 1946 'apparently as reinsurance of British citizenship'. ${ }^{48}$ This paid off in the representation and attention he received while detained. Similarly, his arrival in Lesotho did not end his political work, as he worked closely with Matthews to run a thriving ANC branch. The ANC bank account in Maseru was under their names until Letele's passing in $1965 .{ }^{49}$ With Matthews focused on external fundraising, Letele's role was to facilitate the flight of other refugees into Lesotho and support them once they arrived. His most famous case was that of Anderson Ganyile, who fled to Lesotho, was brazenly abducted by South African police from the territory in 1961 and, after an international outcry, returned in $1962 .{ }^{50}$ But Letele did not just stay in Lesotho. Using the CUKC passport he obtained after arrival, he made trips on behalf of the ANC to Nigeria, Tanganyika, Egypt, Sweden, the UK and the USSR. Between Letele and Matthews, the ANC had two key figures based in Lesotho in the early 1960s, both of whom made extensive use of British passports to press the ANC's agenda abroad at a critical juncture when the organisation was banned in South Africa.

PAC leaders also made use of the British passports on offer in Lesotho. Mokhalake Elias Ntloedibe arrived in 1961 and gained residency through the ERP. He received a British passport in October 1962, which allowed him to travel to Ghana to take up the position there of chief representative for the PAC. ${ }^{51}$ Similarly, Potlako Leballo, born in Lesotho, returned to the territory after being released from his post-Sharpeville detention in 1962. He too applied for and received a CUKC passport that he used to travel extensively throughout Africa and beyond in the 1960s. ${ }^{52}$ The liberation groups thus made extensive use of British passports obtained in Lesotho to allow their leaders to further the aims of the groups internationally, but it was not only external groups taking up passports in increased numbers.

Local people in Lesotho were also obtaining CUKC passports in much greater numbers, but South Africa's 1961 commonwealth departure was a greater catalyst for their applications rather than the Sharpeville massacre. Again, archival limitations in Lesotho make it impossible to determine the exact number of Basotho who took this option, but the evidence available suggests that demand spiked after May 1961. In the Leribe district from May to September 1961 there was a significant increase in demand for UK passport applications from local residents. While a few Basotho had applied every year in the 1950s, primarily for the purpose of studying abroad, on 30 May 1961 the district commissioner requested from Maseru 24 ' $\mathrm{C} 1$ passport forms' as 'I am at present completely out of stock ... and there is a great demand for them'. By 9 June 1961, officials had 'issued all the [passport applications] and had eight more applicants on the waiting list'. Again on 21 June, the office requested twodozen more passport applications. This spike in demand continued with further requests for forms on 10 July and 27 September. ${ }^{53}$ In all, at least 100 
Basotho applied for CUKC passports from this particular district office in just over four months following the commonwealth departure. The largest number of applicants in Lesotho would probably have come from the Maseru office, an office for which we do not have numbers. Extrapolating from more than 100 Leribe applicants and nine districts total in Lesotho, it is safe to say that the number of Basotho applying for the first time for a CUKC passport was probably in the low thousands in the months and years immediately following South Africa's commonwealth departure. The speed with which Basotho applied for passports suggests that a significant number of Basotho keenly understood the potential benefits of claiming British citizenship and passports. They were careful observers of how regional events impacted their lives, and many understood that, for all the resistance Basotho had to the idea of colonialism in general, obtaining a CUKC passport in the early 1960s would better secure and protect the freedoms of movement, employment and travel opportunities they valued.

\section{From Migrant to Asylum Seeker: Citizenship and Decolonisation}

The increase in the number of passport seekers by Lesotho 'belongers' and refugees alike shows a growing awareness in the late colonial period of the importance that formal identity documents played in securing and protecting individuals' citizenship rights. Disputes over who had access to these papers, and thus citizenship, later in the 1960s, however, highlight the fact that political independence in many cases left messy questions about citizenship and residency unresolved for individuals. The experiences of political refugees like Wycliffe Tsotsi and Joe Molefi also bring into focus the limits of sovereignty that continued colonial obligations put on both Lesotho and the United Kingdom in the decolonisation era.

Wycliffe Tsotsi was president from 1948 to 1958 of the All-African Convention (AAC), a group originally formed in 1935 to oppose South African attempts to disenfranchise Africans in the Cape through the Representation of Natives Act. The strength of the AAC lay in the Transkei region of the rural eastern Cape that was located close to Lesotho's southwest border. The South African government, in part, blamed the organisation for the Pondoland Uprising of $1960 .^{54}$ When the government declared a state of emergency in the Transkei in December 1960, Tsotsi fled to Lesotho. He took up residence in Maseru where he worked as an attorney, often in conjunction with Joe Matthews. He applied for his residence permit in January 1961, and his case came before the central control board at the same time as Matthews' application in September of that year. Unlike Matthews, however, Tsotsi was denied an indefinite residence permit as he had applied as a political refugee. The board members rejected his application because the state of emergency in the Transkei had ended, and they deemed him to be not a 'genuine refugee' because he was no 
longer 'liable for arrest in the Republic'. ${ }^{55}$ This rationale, however, obscured the real issue, which was that Tsotsi did not have the same good connections that Matthews enjoyed with Basotho political leaders and the monarch. His law work had included taking on the cases of PAC leaders who were gradually wearing out their welcome in Lesotho among certain segments of the local political class. Without Matthews' personal connections, Tsotsi's application fell victim to fears expressed by Moshoeshoe II in September 1961 of 'the continued presence in Basutoland of the undesirable element [politically] from the Union'. ${ }^{56}$ Moshoeshoe II and other Basotho political leaders worried that the presence of high-profile political refugees like Tsotsi and the PAC leadership in Maseru could sour relations between Lesotho and South Africa enough to complicate or delay the push for Lesotho's independence.

Tsotsi did not accept the denial of his residency application and continued to appeal his case. With international support from UK anti-colonial MP Fenner Brockway, among others, Tsotsi managed to get a series of short-term temporary residency permits to stay in the territory. He also attempted to bypass the central control board by persuading the chief of Thaba Bosiu to accept him in 1962 as a 'belonger', which should have entitled him to a permanent residency permit. ${ }^{57}$ It is unclear exactly why, but this stratagem also failed. It is likely, though, that the authorities-Basotho and British-saw this as a disingenuous attempt by Tsotsi, as he was certainly not resident in the rural area around Thaba Bosiu under the chief s jurisdiction. Despite his failure to gain some sort of permanent residency, he did obtain a CUKC passport on 11 February 1964, with citizenship applied retroactively to 30 June 1962. While he lacked political connections at the highest level locally, his connections abroad did help stay the hands of the colonial authorities.

Like the ANC leaders in Maseru, Tsotsi continued his South African political work while domiciled in Lesotho. He took multiple clandestine trips across the border to meet with AAC leadership still in South Africa. In September 1964, after one of these meetings in Durban, the South African police stopped his vehicle and detained Tsotsi under the 90-day law. His recently established British citizenship allowed him to received consular visits from British officials, but South African authorities who wanted to keep him in detention denied that he had given up or lost his South African citizenship. ${ }^{58}$ Basotho authorities on the Executive Council in Lesotho were unhappy that Tsotsi had received British citizenship and a CUKC passport. They had been the ones to deny his residency requests, but, since it was the UK government that issued passports, there was little they could do other than point out that he still did not have permanent or indefinite residency rights. The minutes of the control board meeting dryly noted this fact, saying that his 'residence was being dealt with under the Basutoland E\&RP', suggesting that despite the passport and status as a British subject, he was still not going to be able to claim local 'belonger' status. ${ }^{59}$ His inability to formalise residency despite his ability to claim British citizenship 
would dramatically and negatively impact Tsotsi after Lesotho's 1966 independence. His case, in particular, underscores that plenty of leaders and individuals clearly understood the power of residency, citizenship and official papers even in the colonial period.

After Tsotsi was released from a South African prison in December 1964, he returned to Lesotho where he expanded his law practice, especially in the wake of Matthews' deportation in 1965. He was one of the only local lawyers willing and able to take political cases. His own legal battle to receive permanent or indefinite residency in Basutoland prior to independence in October 1966, however, failed. By law, his British citizenship was supposed to turn into Lesotho citizenship at the transfer of power, but this did not happen. In late 1966 the Lesotho authorities deported him to South Africa, claiming he was not a legal resident of the new state. This deportation came about largely because Tsotsi made himself an enemy of the ruling Basotho National Party (BNP) government by representing both King Moshoeshoe II and the opposition BCP in separate cases seeking to limit the power of the BNP leaders at independence. ${ }^{60}$ While the deportation came about officially because Tsotsi failed to secure a residency permit, it also showed his personal malleability, as he had neutralised Moshoeshoe II's earlier opposition to his residency by acting as his advocate in court. Still, Tsotsi became the most visible public face of refugees who were, in the BNP government's view, working to subvert the independence and sovereignty of Lesotho.

One of the first BNP legislative priorities after independence was passing the Aliens Control Act of 1966 to replace the colonial ERP. Part of this law included provisions to better control and surveil refugees by forcing them to apply for permanent, indefinite or temporary residence permits prior to arrival in Lesotho and making deportation an easier process. ${ }^{61}$ In the wake of an opposition protest that turned deadly when the Lesotho police opened fire on and killed protestors, the Lesotho government deported Tsotsi through the Maseru Bridge border crossing on 28 December 1966. Able to quickly escape the South African border jail where he was initially placed, Tsotsi returned to Lesotho later that same day and requested political asylum at the British High Commission offices. The high commissioner refused his request on the grounds that they now considered him to be a Lesotho citizen rather than a British subject, and he, therefore, needed to talk to the same Lesotho authorities responsible for his deportation. After a short stint in prison in Lesotho, and following negotiations with the government, Tsotsi agreed to leave for Zambia on 13 January 1967. The Lesotho government decided they would rather pay transportation costs for Tsotsi and his wife and negotiate with the South African government to allow him passage than acknowledge the legitimacy of Tsotsi's citizenship, acquired through the vagaries of British late colonial policy. ${ }^{62}$

If Tsotsi's story ended there, it would still be a remarkable example of lingering colonial obligations imposing burdens on supposedly independent 
governments, but, by retaining and maintaining a claim to Lesotho citizenship, Tsotsi ensured that the story continued. His ability to work or travel onward from Zambia was extremely limited because he lacked a Lesotho passport, and the Zambian government would not issue him papers either. The Zambians worried that issuing papers would formalise his refugee status and turn him into their obligation. Thus, Tsotsi spent the period from 1967 until 1978 stateless and trapped in Zambia. Tsotsi's citizenship limbo finally ended in 1978. With the Lesotho government's diplomatic priorities rapidly changing, he was able not only to gain his long-coveted Lesotho citizenship, but also to return to Maseru where he took a job as a top government lawyer. He had finally 'made my peace with the Lesotho government and had even obtained Lesotho passports'. 63

The journey of Tsotsi that started with his arrival in Lesotho in late $1960 \mathrm{did}$ change at independence, but for him, it was not immediately a change for the better. Despite his British citizenship, he had failed to gain local residency. Since Basotho controlled the gate for that status, the Lesotho government after independence felt within its rights to challenge Tsotsi's eligibility for citizenship and a passport. While his CUKC passport was no longer valid after independence, his request for British asylum in late 1966 suggests that Tsotsi did not view British obligations to him as complete despite the transfer of power. Tsotsi, however, remained a thorn in the government's side, as well as a reminder of the colonial legacy that they could not shed. The Lesotho, British and even Zambian governments wished to be done with Tsotsi and his complicated colonial-era case, but with his status unresolved none could effectively police the boundaries of national sovereignty or easily dispose of unwanted individuals.

The case of Joseph Sallie Poonyane Molefi also highlights the role that lingering colonial obligations played in the calculations of both the Lesotho and UK governments. Yet another treason trial defendant from late 1950s South Africa, Molefi jumped bail in a separate case in 1961, fleeing to Lesotho. Working as a journalist, Molefi was first active in the PAC in Maseru, though he split with them in 1963 because he disagreed with the organisation's turn to violence. He petitioned the British government for asylum in 1962, asking for 'written security for [refugees'] continued stay without interference' as a way of formalising his status in the territory, but was turned down and told to use the ERP process. $^{64}$ Molefi's petition was remarkably prescient, as the Tsotsi case later proved, and it underscored how much the British government resisted having long-term legal responsibility for refugees as the empire wound down. The failure of this petition, and his inability or unwillingness - the record is not clear-to attempt a permanent residence permit through the ERP meant that Molefi, like Tsotsi, lived in Lesotho on a series of temporary residence permits. The last of these permits expired on 31 December 1967. By this time, of course, Lesotho was independent, and Molefi was working as a respected professional journalist for South African newspapers, American wire services and 
the BBC. He, like Tsotsi, fell out of favour with the BNP government. He had filed a critical story about the BNP after the 1965 election, and so, when his temporary residence permits finally ran out, he too faced deportation. ${ }^{65}$

Molefi fought his deportation order in the courts and used his international political connections to mobilise support. He exhausted his appeals in Lesotho and even took his case to the Privy Court in London. While his case was also part of the BNP government's wider crackdown on refugees in Lesotho, there was a degree of protection for high-profile refugees like Molefi. That does not mean, however, that Molefi and other refugees could ignore anti-refugee public proclamations, like the one Prime Minister Jonathan made giving refugees 30 days to leave Lesotho from 31 August 1968 or face criminal charges. That particular order caused Molefi again to request political asylum in the United Kingdom from the high commissioner in Maseru. The British again turned down this asylum request, as they did with Tsotsi, arguing that Molefi was supposed to have citizenship in Lesotho. While Prime Minister Jonathan did not carry through on his threat to arrest and deport all refugees, such threats had to be taken seriously. ${ }^{66}$ Molefi, unlike the others detailed here, never availed himself of a CUKC passport in the colonial period, retaining his South African citizenship, and he lost his final appeal before the Lesotho High Court on 15 January 1969 when it ruled that he did not legally have the status of refugee and could be deported. ${ }^{67}$

The Lesotho government acted, as they did with Tsotsi, as if the British government should have responsibility for Molefi because his applications for indefinite residency before a Basotho-majority board in the colonial period had failed. The government saw this as evidence that he was not entitled to 'belonger' status in Lesotho because representatives of the national community had rejected his application. However, international pressure, coming in large part from the former colonial government in London, again hindered the ability of the Lesotho government to fully police the boundaries of national citizenship. Thus, Molefi's case remained in legal limbo too. From the British perspective, the government did not want to create a precedent for allowing a class of asylum seekers from southern Africa. Rising anti-immigrant sentiment in the UK during the 1960s made acceptance of asylum claims a severe political liability. Officials in London worried that, if they accepted Molefi, southern African governments would 'simply off-load' their unwanted and troublesome South African refugees on the United Kingdom by 'threatening to expel them' and, thus, getting the UK to grant asylum. ${ }^{68}$ Therefore, the UK government pushed the Lesotho government to accept Molefi as a Lesotho citizen so as to extinguish the possibility of successful asylum claims on the UK. ${ }^{69}$

Despite its opposition to Molefi's asylum requests and citizenship claims, however, the UK government was not averse to having Molefi within its borders. The UK offered to allow Molefi to enter on a work permit, as long 
as he had a job lined up and the Lesotho government would issue him a passport. From the perspective of the British government, not only would a Lesotho passport allow them to offload Molefi were he to get into trouble, but it would also force the Lesotho government to validate his claim to citizenship, and thereby end his potentially embarrassing asylum claims. ${ }^{70}$ The Americans also expressed a willingness to accept him on a similar deal. ${ }^{71}$ Molefi never took up the offer of a work visa, in part because the Lesotho coup of January 1970 disrupted normal diplomatic communications, but largely because he wanted to stay in the southern African region. As with Tsotsi, Molefi was able to reconcile with the Lesotho government later in the 1970s as its priorities shifted. He formalised his status in Lesotho and resided there until his death in 2003.

The cases of Tsotsi and Molefi illustrate not only how important the acquisition of formal papers was to refugees, but also highlight that they were key markers to governments attempting to draw the boundaries of citizenship and sovereignty in the decolonisation period. Passports were, of course, not a foolproof method of claiming rights for individuals, but in all the cases when people had such a document, it conferred important protections. The obligations into which formal papers forced governments were also one reason why the Lesotho and UK governments drew such stringent lines around who had access to documents. In the case of citizenship claims originating in late colonial Lesotho, governmental decisions made in the waning days and years of the colonial period limited the ability of the independent Lesotho government to fully police the boundaries of citizenship. At the same time, however, the cases also limited the ability of the British government to fully sever its colonial obligations to individuals who had received citizenship, even after the formal transfer of power.

\section{Conclusion}

The cases of refugees are most salient in the archival record, especially those who were able to marshal transnational interest in their cases. It was, however, not simply high-profile refugees who understood the symbolic and real power of official citizenship documents, as the number of Basotho taking up passports in the wake of the South African commonwealth departure in 1961 showed. The imposition of South African border controls with Lesotho in 1963 caused a large increase in the number of Basotho seeking to regularise their status as 'belongers' in Basutoland/Lesotho. Prior to South Africa's commonwealth departure most Basotho had little need for a passport because they could freely enter South Africa without one. Between 1961 and November 1965, the colonial government issued 206,000 local passports to Basotho. The de jure population of Lesotho at that time, for comparison, was around 800,000. A local passport was a simplified identity document conferring 'belonger' status 
on the bearer that allowed Basotho to maintain visa-free entry into South Africa. Many therefore took out the document because it entitled them to continue to seek employment in South Africa's rural areas. ${ }^{72}$ The number of Basotho formalising their citizenship through documentation further continued after independence, with, for example, the Lesotho government issuing 46,622 local passports in $1971 .^{73}$

Basotho used these papers to visit South African friends and relatives, shop and find work throughout the remainder of the apartheid era, but they were much more than simply entry papers. Many Basotho deliberately overstayed their permitted time in South Africa to continue their work or pursue educational opportunities. South African authorities complained in 1971 that over 10,000 of 70,000 legal Basotho entrants had overstayed, with most overstayers illegally residing in the urban areas to pursue employment opportunities. ${ }^{74}$ What was new after independence for Basotho was that their passports allowed legal entry into South Africa. Thus, migrants often tried to slip back across the border into Lesotho without having to show their crucial identity document if they had overstayed. South African officials complained in 1972 that many Basotho had 'disposed of their passports and other documents of identity with the object to prevent or hamper prosecution and their repatriation' ${ }^{75}$ But Basotho were certainly not 'disposing' of their hard-won passports; rather they were hiding them for future use. Basotho could get an official letter from the Lesotho Labour Bureau in Johannesburg stating the document was lost, and then they could attempt to return to Lesotho utilising that form letter at border crossing, with the passport safely hidden in luggage. In 1972, dozens of Basotho were arrested doing just that after passports were found in luggage in a search at the Maseru Bridge border post. ${ }^{76}$

These deliberate obfuscation attempts by migrant Basotho suggest that understandings of citizenship rights, the importance of passports and border crossing were at least as widespread among citizens of Lesotho as they were with political refugees. With so many having first obtained passports in the colonial period, it also suggests that rapid legal changes in late colonial Basutoland and South Africa's 1961 commonwealth exit 'lived on' in ways that hindered the ability of the Lesotho, South Africa and United Kingdom governments to fully police their sovereignty or access to identity papers. Those living on the margins in the late colonial and early independence worlds of southern Africa did not trust any government to fully protect their rights. When presented with the opportunity, refugees and Lesotho 'belongers' alike eagerly took up the offer of passports, whether issued by Britain or Lesotho. Thus, passports and the claims that various individuals made on governments in the late colonial and early independence periods are wonderful vehicles through which to examine the limits of state sovereignty. The afterlives of empire seen here should serve as a cautionary tale about how we must consider the transfer of power only as one starting place from which to study the decolonisation process. 


\section{Notes}

1. Accessed 21 Dec. 2015, http://www.journalism.co.za/blog/deported-editor-finds-pmssa-secret/.

2. For ease of comprehension, I will refer to the land throughout this article as 'Lesotho' as this is what people in the territory called it at the time. 'Basutoland' will be used only in explicit references to the colonial government. The people who live in Lesotho are called Basotho (plural).

3. Rosenthal, "From "Migrants" to "Refugees", 265.

4. This statement ignores small microstate enclaves like Vatican City and San Marino. Coplan, 'Land from the Ancestors', 978.

5. For more on crossing the Lesotho/South Africa border, see Aerni-Flessner, 'Homemakers, Communists, and Refugees'.

6. Torpey, Invention of the Passport, 1.

7. Shapiro, 'No Exit?', 766-68.

8. Torpey, Invention of the Passport, 2.

9. The literature on the worries in the UK about commonwealth immigration driving changes to citizenship law includes Paul, Whitewashing Britain; Waters, 'Dark Strangers'; Karatani, Defining British Citizenship.

10. Salter, Rites of Passage, 157.

11. Coplan, 'Siamese Twin Towns', 85.

12. Coplan, 'Unconquered Territory'; Coplan, 'A River Runs Through It'; Coplan, 'Land from the Ancestors'.

13. Goulbourne, Ethnicity and Nationalism, 98.

14. Bailkin, 'Where did the Empire Go?', 884.

15. Ibid., 885 .

16. Allman, 'Phantoms of the Archive', 119.

17. Dubow, 'Commonwealth and South Africa', 284-85.

18. Matera, Black London, 2-4; Perry, 'Black Britain', 652-54.

19. Hyslop, 'British State in African Port', 898.

20. Lloyd, 'Britain and the Transformation', 336-37.

21. Constantine, 'Migrants and Settlers', 184-85.

22. 'South Africa: The Citizenship Act', 383.

23. Klaaren, 'Post-Apartheid Citizenship', 224.

24. Ibid., 223.

25. Passes to the Union and Influx Control, 1955-56, Leribe Collection (hereafter LC) 26, National University of Lesotho Archives (hereafter NULA).

26. It would be a mistake to say that refugees were completely beyond the reach of the apartheid state as the South African police routinely violated the borders of the HCTs in pursuit of their political opponents, but the general statement still stands that the HCTs were significantly safer for refugees than being in South Africa.

27. Resident Commissioner quoted in Proceedings of the 47th Session.

28. Resident Commissioner quoted in Proceedings of the 53rd (1958) Session.

29. Councillor Maqoaelane Hlekane quoted in ibid.

30. Councillor 'Mako Molapo quoted in ibid.

31. Aerni-Flessner, Dreams for Lesotho; Rosenberg, Promises of Moshoeshoe, 60-63.

32. Legal Report Under Colonial Regulation 149 (2): Entry and Residence (Amendment) Proclamation 1960, DO35/7357, The National Archives, Kew (hereafter TNA).

33. Hailey, African Survey Revised 1956, 272.

34. Jingoes, Perry and Perry, Chief is a Chief. 
35. Circular No. 17 of 1959, 20 Oct. 1959, DO35/7357, TNA.

36. Resident Commissioner to High Commissioner, 25 Sept. 1959, FCO141/881, TNA.

37. Various court cases, Jan.-July 1962, LC 3/21, NULA.

38. Interview with Joe Matthews by Barbara Harmel and Phil Bonner, 18 Aug. 1994, South African History Archive AL3041, accessed through the Aluka database.

39. High Commissioner Pretoria to Dominion Office, 19 May 1960, DO35/7424, TNA.

40. High Commissioner to Colonial Office, 7 June 1960, DO35/7426, TNA.

41. Interview Zakes Mda, email, 9 Jan. 2016.

42. Handwritten note, 27 Sept. 1961, CO141/880, TNA.

43. Ibid.

44. South African Democracy Education Trust, The Road to Democracy, 21-22.

45. Ambassador to South Africa to Secretary of State for the Colonies, 11 Feb. 1965, CO1048/561, TNA.

46. Extract of letter to Prime Minister, 22 April 1960, DO25/10596, TNA.

47. Question No. 63, 30 June 1960, and confidential letter High Commissioner to Commonwealth Relations Office, 21 July 1960, DO25/10596, TNA.

48. High Commissioner to Commonwealth Relations Office, 8 April 1960, DO25/10596, TNA.

49. Basutoland Intelligence Report, Oct. 1963, CO1048/561, TNA.

50. Badat, Forgotten People, 124; International Coalition of Jurists, South African Incident.

51. Kondlo, Twilight of the Revolution, 105; Special Branch Paper on Pan-African Congress Activities in Basutoland, 22 Nov. 1962, CO1048/564, TNA.

52. Lissoni, 'PAC in Basutoland'.

53. Letters from District Commissioner Leribe to Superintendent of Police, Special Branch, Maseru, May-Sept. 1961, LC 16/4, NULA.

54. For more on the revolts, see Kepe and Ntsebeza, eds, Rural Resistance.

55. Handwritten note, 27 Sept. 1961, FCO141/880, TNA.

56. Notes on meeting between Resident Commissioner and Paramount Chief, 29 Sept. 1961, FCO141/880, TNA.

57. Executive Council meeting, 10 Nov. 1964, FCO141/852, TNA.

58. Maseru to Embassy Pretoria, 30 Sept. 1964, FCO141/852, TNA.

59. Executive Council Minutes 13 and 20 Oct. 1964, FCO141/852, TNA.

60. W. M. Tsotsi, I Was a Refugee-Or Was I?, 7, accessed through Forced Migration Online, 7 Jan. 2016, http://repository.forcedmigration.org/show_metadata.jsp?pid= fmo:2136; Mokitimi, Motsoasele and Mathot, A Life Lived in Love, 24, 42.

61. Geneva Academy of International Humanitarian Law and Human Rights, 'Lesotho Aliens Control Act of 1966, No. 16 of 1966', http://www.geneva-academy.ch/ RULAC/pdf_state/Lesotho-Aliens-Control-Act-1966.pdf

62. A. B. F. Burger, Secretary of Foreign Affairs, 'Border Controls: Lesotho', 5 April 1967, BAO4102/C166/9/1916, National Archives of South Africa, Pretoria (hereafter NASA, PT).

63. W. M. Tsotsi, I Was a Refugee-Or Was I?, 22, emphasis added, accessed through Forced Migration Online, 7 Jan. 2016, http://repository.forcedmigration.org/show_ metadata.jsp?pid=fmo:2136,

64. Joe Molefi to MP Fenner Brockway, 2 April 1962, CO1048/140, TNA.

65. Note on Molefi, High Commissioner Maseru, 5 Dec. 1968, FCO45/151, TNA.

66. High Commissioner Maseru to Foreign and Commonwealth Office, 2 Oct. 1968, FCO29/188, TNA.

67. 'Lesotho High Court Judgment'

68. Note on Molefi, High Commissioner Maseru, 5 Dec. 1968, FCO45/151, TNA. 
69. High Commissioner Maseru to Foreign and Commonwealth Office, 24 July 1969, FCO45/151, TNA.

70. Foreign and Commonwealth Relations Office to Maseru, 24 Dec. 1968, FCO45/151, TNA.

71. Secretary's Weekly Activities Report, Southern Africa, 19 Feb. 1970, Government, Lesotho 1970, Box 1, Records Relating to Botswana, Lesotho and Swaziland, 196975, Office of Southern African Affairs, Bureau of African Affairs, Record Group 59, General Records of the Department of State, United States National Archives, College Park, MD.

72. British Embassy Passport Numbers, Nov. 1965, PM1/4/37 EM1/35, NASA, PT.

73. Lesotho 1971.

74. Murray, Families Divided.

75. South African Police Security Branch to Secretary of Foreign Affairs, 26 July 1972, BAO3234 C43/3/8, NASA, PT.

76. A. J. F. Viljoen, South African Police, Pretoria, to Ministry of Foreign Affairs, Maseru, 18 Jan. 1973, BOA3234 C43/3/8, NASA, PT.

\section{Disclosure Statement}

No potential conflict of interest was reported by the author.

\section{References}

Aerni-Flessner, J. Dreams for Lesotho: Independence, Foreign Assistance, and Development. South Bend, IN: University of Notre Dame Press, 2018.

Aerni-Flessner, J. "Homemakers, Communists, and Refugees: Smuggling Anti-Apartheid Refugees in Rural Lesotho in the 1960s and 1970." Wagadu: A Transnational Journal of Women's and Gender Studies 13 (2015): 183-209.

Allman, J. "Phantoms of the Archive: Kwame Nkrumah, a Nazi Pilot Named Hanna, and the Contingencies of Postcolonial History-Writing." American Historical Review 118, no. 1 (2013): 104-129.

Badat, S. The Forgotten People: Political Banishment under Apartheid. Leiden: Brill, 2013.

Bailkin, J. "Where did the Empire Go? Archives and Decolonization in Britain." American Historical Review 120, no. 3 (2015): 884-899.

Constantine, S. "Migrants and Settlers." In Oxford History of the British Empire, Volume IV,

The Twentieth Century, edited by Judith M. Brown, and Wm. Roger Louis, 163-187. Oxford: Oxford University Press, 1999.

Coplan, D. B. "Land from the Ancestors: Popular Religious Pilgrimage along the South Africa-Lesotho Border." Journal of Southern African Studies 29, no. 4 (2003): 977-993.

Coplan, D. B. "A River Runs through It: The Meaning of the Lesotho-Free State Border." African Affairs 100, no. 398 (2001): 81-116.

Coplan, D. B. "Siamese Twin Towns and Unitary Concepts in Border Inequality." In Respacing Africa, edited by Ulf Enger, and Paul Nugent, 71-88. Leiden: Brill, 2010.

Coplan, D. B. "Unconquered Territory: Narrating the Caledon Valley." Journal of African Cultural Studies 13, no. 2 (2000): 185-206.

Dubow, S. "The Commonwealth and South Africa: From Smuts to Mandela." Journal of Imperial and Commonwealth History 45, no. 2 (2017): 284-314.

Goulbourne, H. Ethnicity and Nationalism in Post-Imperial Britain. Cambridge: Cambridge University Press, 2000. 
Hailey, L. An African Survey, Revised 1956: A Study of Problems Arising in Africa South of the Sahara. Oxford: Oxford University Press, 1957.

Hyslop, J. "A British Strike in an African Port: The Mercantile Marine and Dominion Politics in Durban, 1925." Journal of Imperial and Commonwealth History 43, no. 5 (2015): 882-902.

International Coalition of Jurists. South African Incident: The Ganyile Case. Geneva: International Coalition of Jurists, 1962.

Jingoes, Stimela Jason, with Cassandra Perry and John Perry. A Chief is a Chief by the People. London: Oxford University Press, 1975.

Karatani, R. Defining British Citizenship: Empire, Commonwealth, and Modern Britain. Portland, OR: Frank Cass, 2003.

Kepe, Thembela, and Lungisile Ntsebeza, eds. Rural Resistance in South Africa: The Mpondo Revolts after Fifty Years. Leiden: Brill, 2011.

Klaaren, J. "Post-Apartheid Citizenship in South Africa." In From Migrants to Citizens: Membership in a Changing World, edited by T. Alexander Aleinikoff, and Douglas Klusmeyer, 221-252. Washington, DC: Carnegie Endowment for International Peace, 2000.

Kondlo, K. In the Twilight of the Revolution: The Pan-Africanist Congress of Azania. Basel: Basel Afrika Bibliographien, 2009.

"Lesotho High Court Judgment in Molefi v. Principal Legal Adviser (Convention on Status of Refugees; State Succession).” International Legal Materials 8, no. 3 (1969): 581-587.

Lesotho 1971: Annual Report. Maseru: Government Printing, 1971.

Lissoni, A. "The PAC in Basutoland, c. 1962-65." South African Historical Journal 62, no. 1 (2010): 54-77.

Lloyd, L. "Britain and the Transformation from Empire to Commonwealth." The Round Table 86, no. 343 (1997): 333-360.

Matera, M. Black London: The Imperial Metropolis and Decolonization in the Twentieth Century. Berkeley: University of California Press, 2015.

Mokitimi, M., T. E. Motsoasele, and G. Mathot. A Life Lived in Love, Meshu Mokitimi: How I Remember My First 90 Years. Maseru: Epic Printers, 2016.

Murray, C. Families Divided: The Impact of Migrant Labour in Lesotho. Cambridge: Cambridge University Press, 1981.

Paul, K. Whitewashing Britain: Race and Citizenship in the Postwar Era. Ithaca, NY: Cornell University Press, 1997.

Perry, K. H. "Black Britain and the Politics of Race in the 20th Century." History Compass 12, no. 8 (2014): 651-663.

Proceedings of the 47th Session of the Basuto National Council, 10 Sept 1951. Maseru: Government Printing, 1952.

Proceedings of the 53rd (1958) Session of the Basutoland Council, Feb-Mar 1958. Maseru: Government Printing, 1959.

Rosenberg, S. Promises of Moshoeshoe: Culture, Nationalism, and Identity in Lesotho. Roma, Lesotho: Institute of Southern African Studies, 2008.

Rosenthal, J. "From 'Migrants' to 'Refugees': Identity, Aid, and Decolonization in Ngara District, Tanzania." Journal of African History 56, no. 2 (2015): 261-279.

Salter, M. B. Rights of Passage: The Passport in International Relations. Boulder, CO: Lynne Rienner, 2003.

Shapiro, K. "No Exit? Emigration Policy and the Consolidation of Apartheid." Journal of Southern African Studies 42, no. 4 (2016): 763-781.

"South Africa: The Citizenship Act." The Commonwealth Journal of International Affairs 39, no. 153-156 (1948): 383-387. 
South African Democracy Education Trust. The Road to Democracy: South Africans Telling Their Stories, Vol. 1, 1950-1970. Houghton: Mutloatse Arts Heritage Trust, 2008.

Torpey, J. The Invention of the Passport: Surveillance, Citizenship and the State. Cambridge: Cambridge University Press, 2000.

Waters, C. "Dark Strangers' in Our Midst: Discourses of Race and Nation in Britain, 19471963.” Journal of British Studies 36, no. 2 (1997): 207-238. 